\title{
A Novel Case of Concurrent T-cell and Early T-cell Lymphoblastic Lymphoma in an Adolescent Female: A Brief Report
}

\author{
Charles Treinen ${ }^{1}$, Mohammad Abu Arja ${ }^{2}$, Samir Kahwash ${ }^{1}$, Hemalatha Rangarajan ${ }^{1}$, Faye \\ Willen $^{1}$, and Anthony Audino ${ }^{3}$ \\ ${ }^{1}$ Nationwide Children's Hospital \\ ${ }^{2}$ New York-Presbyterian Brooklyn Methodist Hospital \\ ${ }^{3}$ Nationwide Children's Hospital Department of Pediatric Hematology Oncology and Bone \\ Marrow Transplants
}

November 13, 2020

\begin{abstract}
In the context of an evolving understanding of early T-cell precursor (ETP) lymphoma and leukemia, we present a case of concurrent $\mathrm{T}$ cell lymphoblastic lymphoma and ETP lymphoma in an adolescent female. To our knowledge, this represents the first reported case of both lymphoblastic lymphoma and ETP lymphoma as distinct and conjoined components of the same neoplasm. As an exception to current literature, our patient had only ETP lymphoma with no marrow involvement. Her ETP component remained viable following induction, supporting ETP resistance to chemotherapy. The patient remains in remission 4 years post allogeneic matched sibling donor bone marrow transplant.
\end{abstract}

\section{Hosted file}

ETPLy_25 (1).pdf available at https://authorea.com/users/375593/articles/492758-a-novelcase-of-concurrent-t-cell-and-early-t-cell-lymphoblastic-lymphoma-in-an-adolescentfemale-a-brief-report

\section{Hosted file}

Table 1.pdf available at https://authorea.com/users/375593/articles/492758-a-novel-caseof-concurrent-t-cell-and-early-t-cell-lymphoblastic-lymphoma-in-an-adolescent-female-abrief-report 

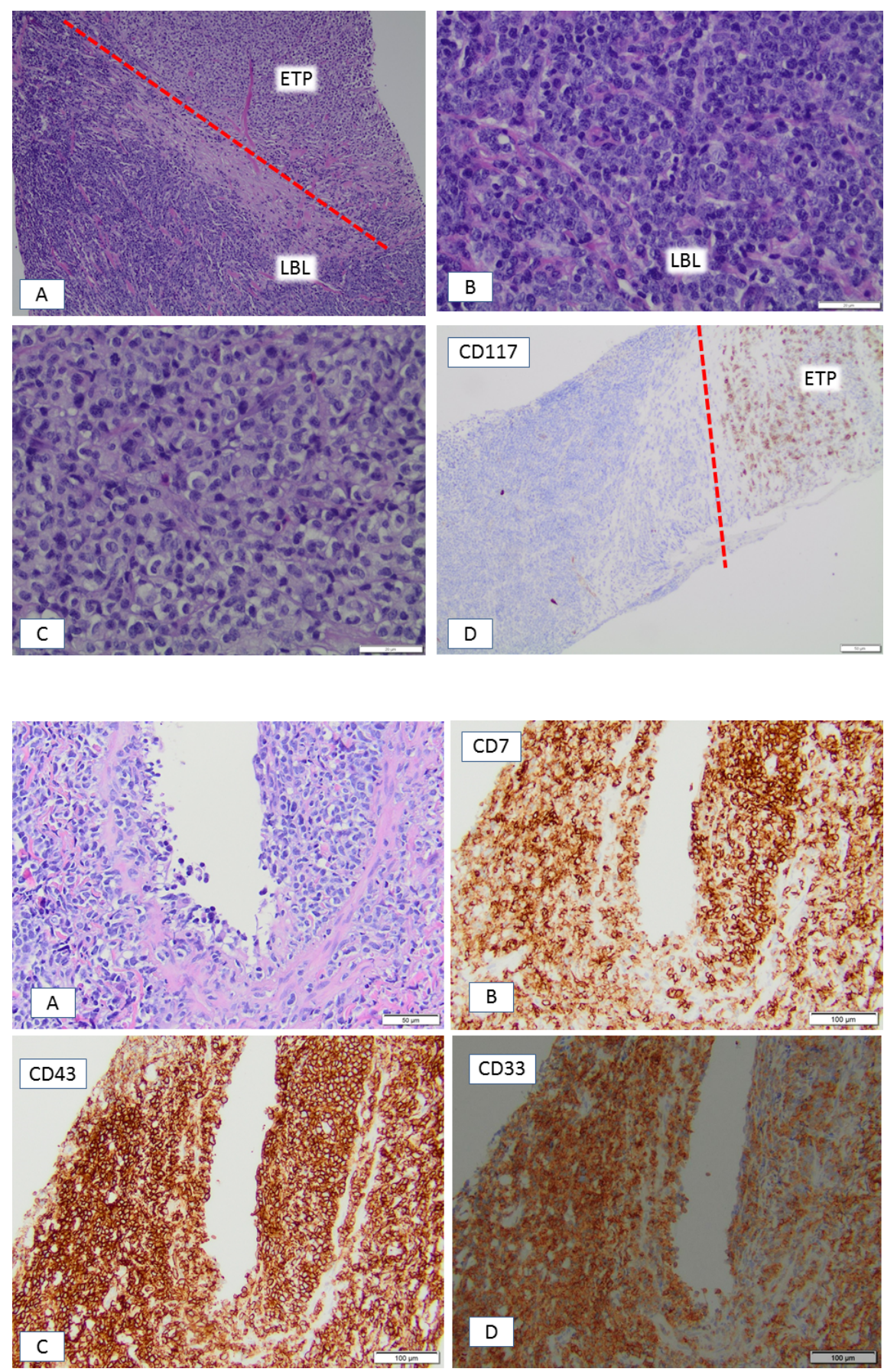